\title{
KUALITAS DNA HASIL PURIFIKASI DARI SOSIS SAPI SEBAGAI BAHAN AUTENTIKASI HALAL BERBASIS MARKER GENETIK
}

\author{
(DNA Quality of Purification from Beef Sausage as Halal Authentication Material Based on \\ Genetic Marker)
}

\author{
Nurul Purnomo ${ }^{1}$, Dhian Ramadhanty ${ }^{1}$, Musdalifa Mansur ${ }^{1}$, Maghfira Nur², \\ dan Muhammad Ihsan A. Dagong 2,3. \\ ${ }^{1}$ Program Studi Peternakan , Universitas Muhammadiyah Sidenreng Rappang, \\ Jl. Angkatan 45 No. 1A Lt. Salo Sidenreng Rappang, 91651 \\ ${ }^{2}$ Laboratorium Bioteknologi Terpadu Fakultas Peternakan Universitas Hasanuddin, \\ Jl. Perintis Kemerdekaan KM. 10, Tamalanrea Indah, Kec. Tamalanrea, Kota Makassar, Sulawesi Selatan 90245 \\ ${ }^{3}$ Departemen Produksi Ternak Fakutas Peternakan Universitas Hasanuddin, \\ Jl. Perintis Kemerdekaan KM. 10, Tamalanrea Indah, Kec. Tamalanrea, Kota Makassar, Sulawesi Selatan 90245 \\ Email korespondensi: purnomo.nupo@gmail.com
}

\begin{abstract}
This study aims to determine the effect of the preparation method and the number of samples on the quality of purified DNA from beef sausage. The study was conducted using a Randomized Block Design. The main factor is the sample preparation method which consists of P1: fresh sample; P2: oven-dried sample; and P3: Freeze-drying dry samples. Each treatment consisted of 4 groups, namely K1: sample weight $25 \mathrm{mg}$; K2: sample weight $50 \mathrm{mg}$; K3: sample weight $75 \mathrm{mg}$; and K4: sample weight $100 \mathrm{mg}$. Each treatment group was repeated 2 times so that the total sample was 24 . The results showed that DNA purification using different preparation methods and sample weights was successfully carried out, as seen from the presence of DNA bands visualized on agarose gel with EtBr staining. The average DNA quality of the P1, P2, and P3 preparation methods were $1.60 \pm 0.90 \mathrm{ng} / \mu \mathrm{l}, 2.63 \pm 0.99 \mathrm{ng} / \mu \mathrm{l}$, and $2.94 \pm 0.89, \mathrm{ng} / \mu 1$ respectively, with DNA purity $1.023 \pm 0.165$, $0.937 \pm 0.148$, and $1.014 \pm 0.163$. The average DNA quality at K1, K2, K3, and K4 obtained DNA concentrations of $3.03 \pm 1.64 \mathrm{ng} / \mu \mathrm{l}, 3.15 \pm 0.74 \mathrm{ng} / \mu \mathrm{l}, 2.28 \pm 1.66 \mathrm{ng} / \mu \mathrm{l}$, and $2.54 \pm 1.50 \mathrm{ng} / \mu \mathrm{l}$ with a purity of $1.059 \pm 0.142,0.981 \pm 0.130,0.908 \pm 0.061$, and $1.061 \pm 0.215$. The average total concentration of purified DNA from beef sausage was $2.75 \pm 1.28 \mathrm{ng} / \mu \mathrm{l}$ with a purity of $0.991 \pm 0.149$. The results of variance showed that the treatment did not affect the concentration and purity of purified DNA from beef sausage. This study concludes that DNA purification from beef sausage can be carried out, but the preparation method and number of samples do not affect the quality and quantity of DNA.
\end{abstract}

Keywords : halal authentication, genetic markers, processed livestock products, DNA purification, halal food

\section{ABSTRAK}

Penelitian ini bertujuan untuk mengetahui pengaruh metode preparasi dan jumlah sampel terhadap kualitas DNA hasil purifikasi dari sosis sapi. Penelitian dilakukan menggunakan Rancangan Acak Kelompok. Faktor utama adalah metode preparasi sampel yang terdiri dari P1 : sampel segar; P2 : sampel kering-oven; dan P3 : sampel kering Freeze-drying. Setiap perlakuan terdiri dari empat kelompok, yaitu K1 : berat sampel $25 \mathrm{mg}$; K2 : berat sampel $50 \mathrm{mg}$; K3 : berat sampel $75 \mathrm{mg}$; dan K4 : berat sampel $100 \mathrm{mg}$. Masing-masing kelompok perlakuan diulang sebanyak 2 kali, sehingga total sampel 24 . Hasil penelitian menunjukkan bahwa purifikasi DNA menggunakan metode preparasi dan berat sampel yang berbeda berhasil dilakukan, terlihat dari adanya pita DNA hasil visualisasi pada gel agarose dengan pewarnaan EtBr. Rata-rata kualitas DNA dari metode preparasi P1, P2 dan P3 masing-masing 1,60 $\pm 0,90 \mathrm{ng} / \mu \mathrm{l}, 2,63 \pm 0,99 \mathrm{ng} / \mu \mathrm{l}$, dan 2,94 $\pm 0,89 \mathrm{ng} / \mu \mathrm{l}$ dengan kemurnian DNA masing-masing 1,023 $\pm 0,165,0,937 \pm 0,148$, dan $1,014 \pm 0,163$. Rata-rata kualitas DNA pada K1, K2, K3 dan K4 diperoleh konsentrasi DNA masingmasing 3,03 $\pm 1,64 \mathrm{ng} / \mu \mathrm{l}, 3,15 \pm 0,74 \mathrm{ng} / \mu \mathrm{l}, 2,28 \pm 1,66 \mathrm{ng} / \mu \mathrm{l}$, dan 2,54 $\pm 1,50 \mathrm{ng} / \mu \mathrm{l}$ dengan kemurnian masing-masing $1,059 \pm 0,142,0,981 \pm 0,130,0,908 \pm 0,061$, dan $1,061 \pm 0,215$. Rata-rata total konsentrasi 
DNA hasil purifikasi dari sosis sapi yaitu $2,75 \pm 1,28 \mathrm{ng} / \mu \mathrm{l}$ dengan kemurnian $0,991 \pm 0,149$. Hasil sidik ragam menunjukkan perlakuan tidak mempengaruhi konsentrasi dan kemurnian DNA hasil purifikasi dari sosis sapi. Kesimpulan penelitian ini yaitu purifikasi DNA dari sosis sapi dapat dilakukan, tetapi perlakuan metode preparasi dan jumlah sampel tidak mempengaruhi kualitas dan kuantitas DNA.

Kata Kunci : autentikasi halal, marker genetik, olahan hasil ternak, purifikasi DNA, pangan halal

\section{PENDAHULUAN}

Sosis adalah produk pangan olahan yang terbuat dari campuran daging halus dengan penambahan tepung atau pati dan bumbu tambahan yang dimasukkan kedalam selongsong sosis (Herlina et al., 2015). Penerimaan konsumen terhadap sosis di Indonesia cukup baik, terlihat dengan adanya peningkatan konsumsi rata-rata $4,46 \%$ pertahun (Santoso et al., 2018). Sama seperti produk daging maupun olahan daging lainya, sosis juga memiliki kerentanan yang tinggi terhadap pemalsuan dengan daging lain. Daging hewan lain yang umum digunakan untuk memalsukan daging halal adalah daging babi, anjing, kucing dan tikus.

Pemalsuan daging halal pada olahan daging seperti sosis dengan daging hewan non-halal merupakan isu sensitif di Indonesia. Hal ini disebabkan mayoritas penduduk Indonesia adalah muslim yaitu mencapai 204,8 juta (Charity, 2017) atau 87,18\% dari penduduk Indonesia (Al-Fatih and Aditya, 2017), dan bagi umat muslim memiliki kewajiban untuk mengkonsumsi makanan yang halal dan dilarang mengkonsumsi makan haram sebagaimana yang tertuang dalam Al-Qur'an Surat Al-Maaiddah ayat 88 (Zulaekah and Kusumawati, 2015). Untuk menjamin kehalalan produk pangan termasuk sosis, pemerintah telah menerbitkan Undang-Undang No. 33 Tahun 2014 Tentang Jaminan Produk Halal (AlFatih and Aditya, 2017), bahwa semua produk yang beredar di Indonesia terutama pangan harus sertifikat halal. Sertifikat dikeluarkan oleh Badan Penyelenggara Jaminan Produk Halal (BPJPH).

Saat ini telah dikembangkan beberapa metode autentikasi halal, antara lain metode enzyme-linked immunosorbent assay (ELISA) (Asensio et al., 2008; Kuswandi et al., 2017), electronic nose (e-nose), gas chromatography mass spectrometer with headspace analyzer (GCMS-HS) (Nurjuliana et al., 2011; Kuswandi et al., 2017), imuno- kromatografi atau yang dikenal sebagai rapid test (Kuswandi et al., 2017), polymerase chain reaction (PCR)
(Pestana et al., 2010; Soares et al., 2013; Kim et al., 2016; Al-Kahtani et al., 2017; Perestam et al., 2017), DNA hybridization (Ballin et al., 2009) dan liquid chromatography-mass spectrometry (LC-MS) (Klein-nijenhuis et al., 2018). Metode yang diharapkan dapat diandalkan untuk autentikasi halal pada produk olahan daging seperti sosis adalah dengan menggunakan metode Polymerase Chain Reaction (PCR). PCR merupakan metode ilmiah dalam bidang biologi molekuler untuk menggandakan satu atau beberapa salinan potongan DNA pada beberapa urutan besarnya, menghasilkan ribuan hingga jutaan salinan urutan DNA tertentu (Joshi and Deshpande, 2011). Metode PCR dapat digunakan untuk mengidentifikasi spesies makhluk hidup menggunakan DNA Barkode (Hebert et al., 2003). Dengan kemampuan mengidentifikasi spesies maka kita bisa mengetahui jenis daging apa saja yang digunakan dalam pembuatan sosis, sehingga jika ada campuran daging non-halal bisa diidenfikasi.

Untuk melakukan autentikasi halal menggunakan metode PCR diperlukan DNA template yang berasal dari sampel dengan konsentrasi dan kemurnian yang baik. Namun saat ini belum ada panduan yang jelas tentang metode preparasi dan jumlah sampel sosis untuk autentikasi halal menggunakan metode PCR. Dengan demikian diperlukan penelitian tentang metode preparasi dan jumlah sampel sosis sebagai bahan autentikasi halal berbasis marker genetik menggunakan PCR. Penelitian ini bertujuan untuk mengetahui kualitas DNA hasil purifikasi dari sosis sapi dengan metode preparasi dan jumlah sampel yang berbeda.

\section{MATERI DAN METODE}

\section{Materi}

Penelitian ini dilaksanakan di Laboratorium Bioteknologi Terpadu Fakultas Peternakan Universitas Hasanuddin, Makassar. Bahan sampel yang digunakan adalah sosis sapi Bernardi ${ }^{\circledR}$ yang diproduksi PT. Eloda Mitra. Untuk ektrasi DNA menggunakan Tia Namp 
Genomic DNA Kit ${ }^{\circledR}$ dari Tiangen Biotech (Beijing),.Co.LTD.

\section{Metode}

Penelitian ini dilaksanakan menggunakan Rancangan Acak Kelompok yang terdiri dari 3 perlakuan dan 4 kelompok. Perlakuan 1: sampel segar (P1); perlakuan 2: sampel keringoven (P2); dan perlakuan 3: sampel kering Freeze-drying (P3). Setiap perlakuan terdiri dari 4 kelompok, yaitu kelompok 1: berat sampel $25 \mathrm{mg}$ (B1); kelompok 2: berat sampel $50 \mathrm{mg}$ (B2); kelompok 3: berat sampel $75 \mathrm{mg}$ (B3); dan kelompok 4 : berat sampel $100 \mathrm{mg}$ (B4). Masingmasing kelompok perlakuan diulang sebanyak 2 kali, sehingga total sampel menjadi 24 .

Prosedur kerja penelitian ini yaitu: menyiapkan sampel sosis sapi sesuai kebutuhan. Sampel sosis sapi kemudian digerus hingga halus menggunakan mortar. Menimbang sampel untuk perlakuan 1-3 dengan berat sesuai kelompok perlakuan 1-4 dan masing-masing kelompok perlakuan berjumlah 2 ulangan. Sampel untuk kelompok segar disimpan dalam freezer untuk menunggu sampel kelompok lain siap dipurifikasi. Sampel kering-oven dikeringkan pada oven menggunakan suhu $70^{\circ} \mathrm{C}$ selama 20 jam. Sampel kering Freeze-Drying dikeringkan menggunkan mesin Freeze Drying pada suhu $-40^{\circ} \mathrm{C}$ tekanan 0,12 mbar selama 20 jam. Selanjutnya sampel dipurifikasi mengikuti petunjuk dari TiaNamp Genomic DNA Kit ${ }^{\circledR}$ yang diproduksi oleh Tiangen Biotech (Beijing), Co. LTD. Qualifikasi DNA hasil purifikasi difisualisasi pada gel agaros 1,5\% dengan pewarnaan EtBr. Quantifikasi DNA dilakukan menggunakan spektrofotometer UV VIS Spectrophotometer, Thermo Spectronic, Genesys 10S UV VIS pada panjang gelombang 160 dan $180 \mathrm{~nm}$. Untuk menghitung konsentrasi DNA dan Kemurnian DNA mengacu pada rumus Sambrook et al. (1989):

$$
\begin{aligned}
\text { Konsentrasi DNA }= & A 260 \times 50 \times(\text { faktor } \\
& \text { pengencer })
\end{aligned}
$$

Kemurnian DNA $=$ A260/A280

\section{Parameter yang diamati}

Parameter yang diamati adalah kualitas DNA yang terdiri dari konsentrasi DNA dan kemurnian DNA hasil purifikasi dari sampel sosis sapi.

\section{Analisis data}

Data yang diperoleh dianalisis ragam berdasarkan Rancangan Acak Kelompok (RAK) dengan menggunakan SPSS 16 dari IBM mengacu pada Sudjana (2005).

\section{HASIL DAN PEMBAHASAN}

\section{Visualisasi DNA hasil ekstrak dari sosis sapi pada gel agaros}

Penelitian ini menunjukkan bahwa purifikasi DNA dari sosis sapi menggunakan TiaNamp Genomic DNA Kit ${ }^{\circledR}$ dari Tiangen Biotech (Beijing),.Co.LTD berhasil. Sebagai mana terihat pada Gambar 1 menunjukkan adanya pita-pita DNA dengan panjang lebih dari $30 \mathrm{kbp}$ pada gel agarose 1,5\% dengan pewarnaan EtBr. Hasil visualisasi menunjukkan bahwa terdapat kecenderungan sampel yang dikeringkan (sampel 5 sampai 8 kering oven dan sampel 9 sampai 12 kering beku / freeze-drying) menghasikan DNA dengan konsentrasi lebih tinggi yang ditandai dengan ketebalan pita yang lebih tebal dan jelas. Selain itu, jumlah sampel yang lebih besar juga menunjukkan peningkatan konsentrasi DNA. Gel elektroforesis adalah teknik umum yang digunakan untuk memvisualisasikan protein dan DNA. Elektroforesis gel memungkinkan visualisasi DNA dan RNA dengan penggunaan marker. Proses ini dicapai dengan memisahkan sampel berdasarkan ukuran dan daya listrik. Semakin tinggi konsentrasinya, semakin rapat matriks pemisahannya. Perbedaan konsentrasi akan menentukan panjang pasangan kilobase (kbp) yang divisualisasikan melalui slab. (Anderson et al., 2013).

Agarose adalah polimer linier alami yang diekstraksi dari rumput laut yang membentuk matriks gel dengan ikatan hidrogen setelah dipanaskan dalam buffer dan dibiarkan dingin. Secara umum aplikasi tersebut hanya memerlukan komponen agarose tunggal dan tidak diperlukan katalis polimerisasi. Oleh karena itu, gel agarosa sederhana dan cepat dibuat (Chawla, 2004). Gel agarose merupakan media yang paling popular untuk pemisahan asam nukleat berukuran sedang dan besar dan memiliki jarak pemisahan yang luas tetapi daya pemisahannya relatif rendah, karena pita yang terbentuk di dalam gel cenderung tidak jelas dan menyebar terpisah. Hal ini adalah akibat dari ukuran pori yang tidak 


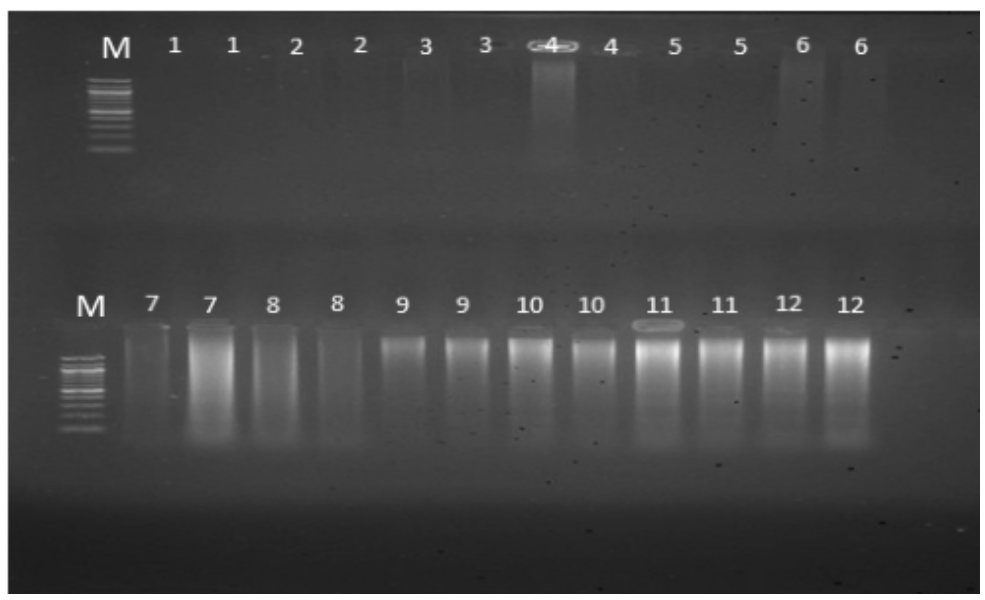

Gambar 1. Fisual DNA hasil purifikasi dari sosis sapi pada gel agaros $1,5 \%$ dengan pewarnaan EtBr. Ket : M (DNA ladder 100 bp); 1 (DNA sosis segar $25 \mathrm{mg}$ ); 2 (DNA sosis segar $50 \mathrm{mg}$ ); 3 (DNA sosis segar $75 \mathrm{mg}$ ); 4 (DNA sosis segar 100 $\mathrm{mg}$ ); 5 (DNA sosis kering oven $25 \mathrm{mg}$ ); 6 (DNA sosis kering oven $50 \mathrm{mg}$ ); 7 (DNA sosis kering oven $75 \mathrm{mg}$ ); 8 (DNA sosis kering oven $100 \mathrm{mg}$ ); 9 (DNA sosis freeze drying $25 \mathrm{mg}$ ); 10 (DNA sosis freeze drying $50 \mathrm{mg}$ ); 11 (DNA sosis freeze drying $75 \mathrm{mg}$ ); 12 (DNA sosis freeze drying $100 \mathrm{mg}$ ).

dapat dikontrol (Stellwagen, 1998). Sementara itu, Ethidium Bromida ditambahkan ke gel untuk meningkatkan visibilitas DNA dalam gel (Anderson et al., 2013). Untuk memvisualisasikan DNA, Etidium Bromida ditambahkan yang memungkinkan visualisasi yang konsisten (Borst, 2005).

\section{Konsentrasi dan kemurnian DNA hasil purifikasi dari sosis sapi}

Hasil pengukuran konsentrasi dan kemurian DNA yang diekstrak dari sosis sapi dapat dilihat pada Tabel 1 dan Tabel 2.

Tabel 1 menunjukkan konsentrasi DNA hasil purifikasi dari sosis sapi dengan kombinasi perlakuan preparasi sampel segar, kering-oven dan freeze-drying dengan perlakuan jumlah sampel 25mg, 50mg, 75mg dan 100mg. Konsentrasi DNA hasil purifikasi dari sosis sapi rata-rata $2,75 \pm 1,28 \mathrm{ng} / \mu \mathrm{l}$, konsentrasi DNA terendah diperoleh pada kombinasi perlakuan sampel segar dengan berat sampel
$75 \mathrm{mg}$ yaitu $0,90 \mathrm{ng} / \mu \mathrm{l}$, sedangkan konsentrasi DNA tertinggi diperoleh pada kombinasi perlakuan freeze-drying dengan jumlah sampel $25 \mathrm{mg}$ yaitu 4,55 ng/ $\mathrm{ll}$. Rata-rata konsentrasi DNA pada metode preparasi sampel segar, kering-oven dan freeze-drying masing-masing $1,60 \pm 0,90 \mathrm{ng} / \mu \mathrm{l}, 2,63 \pm 0,99 \mathrm{ng} / \mu \mathrm{l}$ dan $2,94 \pm 0,89$ $\mathrm{ng} / \mu \mathrm{l}$, sedangkan rata-rata konsentrasi DNA pada berat sampel $25 \mathrm{mg}, 50 \mathrm{mg}, 75 \mathrm{mg}$ dan $100 \mathrm{mg}$ yaitu $3,03 \pm 1,64 \mathrm{ng} / \mu \mathrm{l}, 3,15 \pm 0,74 \mathrm{ng} / \mu \mathrm{l}$, $2,28 \pm 1,66 \mathrm{ng} / \mu \mathrm{l}$ dan $2,54 \pm 1,50) \mathrm{ng} / \mu \mathrm{l}$. Terdapat kecenderungan bahwa konsentrasi DNA pada metode preparasi freeze-drying menghasilkan DNA dengan konsentrasi lebih tinggi dibanding metode preparasi kering-oven dan sampel segar. Sementara pada jumlah sampel, berat sampel $50 \mathrm{mg}$ menghasilkan DNA dengan konsentrasi lebih tinggi dibanding jumlah sampel $25 \mathrm{mg}, 75 \mathrm{mg}$ dan $100 \mathrm{mg}$. Namun, hasil sidik ragam menunjukkan bahwa perlakuan metode preparasi dan jumlah sampel tidak berpengaruh nyata $(\mathrm{P}>0,05)$ terhadap

Tabel 1. Konsentrasi DNA hasil ekstraksi dari sosis sapi dengan metode preparasi dan jumlah sampel yang berbeda.

\begin{tabular}{lccccc}
\hline \multirow{2}{*}{$\begin{array}{l}\text { Preparasi } \\
\text { sampel }\end{array}$} & $\mathbf{5}$ & $\mathbf{5 0}$ & $\mathbf{7 5}$ & $\mathbf{1 0 0}$ & Rata-rata \\
\cline { 2 - 5 } & $\mathbf{2 5}$ & 2,93 & 0,90 & 1,27 & $1,60 \pm 0,90$ \\
Sampel segar & 1,30 & 3,98 & 1,83 & 2,15 & $2,63 \pm 0,99$ \\
Kering oven & 3,25 & 2,55 & 4,13 & 4,20 & $2,94 \pm 0,89$ \\
Freeze drying & 4,55 & $3,15 \pm 0,74$ & $2,28 \pm 1,66$ & $2,54 \pm 1,50$ & $2,75 \pm 1,28$ \\
\hline Rata-rata & $3,03 \pm 1,64$ & & & &
\end{tabular}


Tabel 2. Kemurnian DNA hasil ekstraksi dari sosis sapi dengan metode preparasi dan jumlah sampel yang berbeda.

\begin{tabular}{lccccc}
\hline \multirow{2}{*}{$\begin{array}{l}\text { Preparasi } \\
\text { Sampel }\end{array}$} & $\mathbf{5}$ & $\mathbf{5 0}$ & $\mathbf{7 5}$ & $\mathbf{1 0 0}$ & \multirow{2}{*}{ Rata-rata } \\
\cline { 2 - 5 } & $\mathbf{2 5}$ & 0,958 & 0,902 & 1,267 & $1,023 \pm 0,165$ \\
Sampel segar & 0,964 & 1,121 & 0,800 & 0,837 & $0,937 \pm 0,148$ \\
Kering oven & 0,991 & 0,864 & 0,908 & 1,061 & $1,014 \pm 0,163$ \\
Freeze drying & 1,22 & $0,981 \pm 0,130$ & $0,908 \pm 0,061$ & $1,061 \pm 0,215$ & $0,991 \pm 0,149$ \\
\hline Rata-rata & $1,059 \pm 0,142$ & & & & \\
\hline
\end{tabular}

konsentrasi DNA yang dipurifikasi dari sosis sapi.

Tingkat kemurnian DNA hasil purifikasi dari sosis sapi dengan metode preparasi sampel segar, kering-oven dan freeze-drying dan jumlah sampel $25 \mathrm{mg}, 50 \mathrm{mg}$, $75 \mathrm{mg}$ dan 100 mg disajikan pada Tabel 2. Rata-rata tingkat kemurnian DNA hasil purifikasi dari sosis sapi $0,991 \pm 0,149$, kemurnian DNA terendah 0,800 diperoleh pada preparasi sampel keringoven dengan jumlah sampel $75 \mathrm{mg}$, sedangkan kemurnian DNA tertinggi 1,267 diperoleh pada preparasi sampel segar dengan berat sampel 100 mg. Rata-rata kemurnian DNA pada metode preparsi sampel segar, kering-oven dan freezedrying masing-masing adalah 1,023 $\pm 0,165$, $0,937 \pm 0,148$, dan $1,014 \pm 0,163$. Sementara ratarata kemurnian DNA pada berat sampel 25 $\mathrm{mg}$, $50 \mathrm{mg}$, $75 \mathrm{mg}$ dan $100 \mathrm{mg}$ masing-masing $1,059 \pm 0,142, \quad 0,981 \pm 0,130, \quad 0,908 \pm 0,061$, dan $1,061 \pm 0,215$. Hasil sidik ragam menunjukkan bahwa metode preparasi sampel dan jumlah sampel tidak berpengaruh nyata $(P>0,05)$ terhadap kemurnian DNA yang dipurifikasi dari sosis sapi.

Hasil yang diperoleh pada penelitian ini sejalan dengan Popping et al. (2010) bahwa hasil purifikasi DNA dari produk makanan olahan berkisar 0,1-5 $\mu \mathrm{g} / 100 \mathrm{mg}$ produk. Namun, konsentrasi dan kemurnian DNA yang diperoleh pada penelitian ini jauh lebih rendah jika dibanding konsentrasi dan kemurnian DNA yang diperoleh pada purifikasi DNA dari daging. Hutami et al. (2018) dan Biase et al. (2002) masing-masing melaporkan memperoleh DNA dengan konsentrasi 177,20 - 547,45 ng/ $\mu \mathrm{l}$ dan kemurnian 1,93-1,97 pada daging sapi segar dan konsentrasi 483,3 ng/ $\mu$ l kemurnian 1,80 pada daging babi.

Nilai kemurnian DNA yang baik untuk penelitian molekuler berkisar 1,8-2. Nilai kemurnian DNA kurang dari 1,8 mengindikasikan ekstrak DNA masih mengandung residu phenol dan pelarut lainya. Sedangkan nilai kemurnian lebih dari 2 mengindikasikan ekstrak DNA mengandung kontaminan dari senyawa protein (Sambrook et al., 1989). Konsentrasi DNA yang diperlukan untuk PCR yaitu $10 \mathrm{ng} / \mu \mathrm{l}$, jika konsentrasi DNA terlalu tinggi harus dilakukan pengenceran, sedangkan jika konsentrasi DNA kurang dari $10 \mathrm{ng} / \mathrm{\mu l}$ tidak perlu diencerkan (Seipp et al., 2010).

Meskipun konsentrasi dan kemurnian DNA yang diperoleh dalam penelitian ini berada di bawah standar umum untuk PCR, namun masih ada kemungkinan DNA hasil purifikasi dari sosis sapi dapat digunakan untuk autentikasi halal menggunakan marker DNA. Hal ini didasarkan pada (Riffiani et al., 2015) yang berhasil melakukan amplifikasi DNA bakteri dengan konsentrasi 14,839 $\mu \mathrm{l} / \mathrm{ml}$ dengan kemurnian 0,9581. Selain itu, (Ståhlberg and Kubista, 2018) menyatakan bahwa PCR juga dapat dilakukan menggunakan sampel sel tunggal.

\section{KESIMPULAN DAN SARAN}

\section{Kesimpulan}

Berdasarkan hasil penelitian ini, dapat disimpulkan bahwa purifikasi DNA dari sosis sapi masih dapat dilakukan, namun kualitas DNA hasil purifikasi dari sosis sapi berada dibawah standar umum untuk PCR. Metode preparasi sampel freeze-drying menghasikan DNA dengan konsentrasi dan kemurnian yang lebih tinggi dibanding metode kering-oven dan sampel segar.Jumlah sampel tidak berpengaruh nyata terhadap konsentrasi dan kemurnian DNA hasil purifikasi dari sosis sapi.

\section{Saran}

Perlu dilakukan penelitian lebih lanjut tentang metode purifikasi DNA dari sosis sapi untuk menghasilkan DNA dengan konsentrasi dan kemurnian yang lebih baik. 
Perlu dilakukan pengujian amplifikasi untuk mengetahui jenis primer DNA barkode yang sesuai untuk autentikasi halal pada produk olahan hasil ternak.

\section{UCAPAN TERIMAKASIH}

Penulis mengucapkan terima kasih kepada Kementerian Riset dan Teknologi/ Badan Riset dan Inovasi Nasional yang telah mendanai sepenuhnya penelitian ini melalui Lembaga Penelitian, Publikasi, dan Pengabdian Masyarakat (LP3M) Universitas Muhammadiyah Sidenreng Rappang dengan Skema Penelitian Dosen Pemula (PDP). Penulis juga ingin menyampaikan penghargaan kepada Prof. Asmuddin Natsir yang telah mengizinkan untuk menggunakan Laboratorium Bioteknologi Terpadu Fakultas Peternakan Universitas Hasanuddin Makassar dalam penelitian ini.

\section{DAFTAR PUSTAKA}

Al-Fatih, S., dan Z. F. Aditya. 2017. Perbandingan Hukum Fatwa Halal di Beberapa Negara (Kajian Yuridis Fatwa Halal MUI dan Fatwa Halal dari Lembaga Lain di Luar Negeri. Perbandingan Hukum dan Perkembangan Sistem Hukum. Konvergensi atau Divergensi. Univ. Airlangga, Surabaya. pp 1-25.

Al-Kahtani, H., E. Ismail, and M. Ahmed. 2017. Pork detection in binary meat mixtures and some commercial food products using conventional and real-time PCR techniques. Food Chem., 219: 54-60.

Anderson, J., D. Wright, and K. Meksem. 2013. Agarose Gel Electrophoresis and Polyacrylamide Gel Electrophoresis for Visualization of Simple Sequence Repeats. In Microsatellites. Humana Press, Totowa, N J. pp. 167-177.

Asensio, L., I. González, T. García, and R. Martín. 2008. Determination of food authenticity by enzyme-linked immunosorbent assay (ELISA). Food control, 19(1): 1-8.

Ballin, N., F. Vogensen, and A. Karlsson. 2009. Species determination-Can we detect and quantify meat adulteration. Meat Sci., 83: 165-174.
Biase, F.H., M. M. Franco, L. R. Goulart, and R. C. Antunes. 2002. Protocol for extraction of genomic DNA from swine solid tissues. Genet. Mol. Biol., 25: 313-315.

Borst, P. 2005. Critical review Ethidium DNA agarose gel electrophoresis: how it started. IUBMB life, 57(11): 745-747.

Charity, M. L. 2017. Jaminan Produk Halal di Indonesia (Halal Products Guarantee in Indonesia). J. Legis Indonesia, 14: 99-108.

Chawla,H.S. 2004. Basic techniques. Introduction to plant biotechnology, $2^{\text {nd }}$ edition. Science Publishers, Inc., Enfield, NH, USA.

Hebert, P. D. N., A. Cywinska, S. L. Ball, and R. Jeremy. 2003. Biological identification through DNA barcodes Biological identifications through DNA barcodes. Proceedings of the Royal Society of London. Series B: Biological Sciences, 270(1512) pp. 313-321.

Herlina, I. Darmawan, dan A. S. Rusdianto. 2015. Penggunaan tepung glukomanan umbi Gembili (Dioscorea esculenta L.) sebagai bahan tambahan makanan pada pengolahan sosis daging ayam. J. Agroteknologi, 09: 134-144.

Hutami, R., H. Bisyri, H. Nuraini, dan R. Ranasasmita. 2018. Ekstraksi DNA dari daging segar untuk analisis dengan metode loop-mediated isothermal amplification (LAMP). J. Agroindustri Halal, 4: 209-216

Joshi, M., and J. D. Deshpande. 2011. Polymerase chain reaction: methods, principles and application. Int. J. Biomed. Res., 2: 81-97.

Kim, M., I. Yoo, S. Y. Lee, Y. Hong, and H. Y. Kim. 2016. Quantitative detection of pork in commercial meat products by TaqMan ${ }^{\circledR}$ real-time PCR assay targeting the mitochondrial D-loop region. Food Chemistry, 210: 102-106.

Klein-nijenhuis, A, F. Van-Holthoon, and G. Herregods. 2018. Validation and theoritical justification of an LC-MS method for the animal species specific detection of gelatin. Food Chem., 243: 461-467.

Kuswandi, B., A. Gani, and M. Ahmad. 2017. Immuno strip test for detection of pork adulteration in cooked meatballs. Food Biosci., 19: 1-6. 
Nurjuliana, M., Y. Che-Man, D. Mat-Hashim, and A. Mohamed.2011. Rapid identification of pork for halal authentication using the electronic nose and gas chromatography mass spectrometer with headspace analyzer. Meat Sci., 88: 638-644.

Perestam, A., K. Fujisaki, O. Nava, and R. Hellberg. 2017. Comparison of real-time PCR and ELISA-based methods for the detection of beef and pork in processed meat products. Food Control, 71: 346-352.

Pestana, E., S. Belak, and A. Diallo. 2010. Early Rapid and Sensitive Veterinary Molecular Diagnostics Real-time PCR Application. Springer Science \& Bussiness Media., Dordrecht (DE).

Popping, B., C. Diaz-Amigo, and K. Hoenicke. 2010. Mollecular Biological and Immunological Techniquesand Application for Food Chemists. John Wiley and Sons, Inc., New Jersey, Canada.

Riffiani, R., N. Sulistinah, and B. Sunarko. 2015. Comparison of three dna isolation and purification methods of bacterial DNA. KnE Life Sci., 2: 491-494.

Sambrook, J., F. Fritsch, and T. Miniatis. 1989. Molecular Cloning Laboratory Manual. New York (US): Cold Spring Harbor Laboratory Pr., $3^{\text {rd }}$ ed. Cold Spring Harbor Laboratory Press, Cold Spring Harbor, New York.
Santoso, I., S. A. Mustaniroh, dan D. Pranowo. 2018. Keakraban produk dan minat beli frozen food: peran pengetahuan produk, kemasan, dan lingkungan sosial. Jurnal Ilmu Keluarga \& Konsumen, 11(2): 133144.

Seipp, M. T., M. Herrmann, C. T. Wittwer. 2010. AutomatedDNAExtraction,Quantification, Dilution, and PCR Preparation for Genotyping by High-Resolution Melting. J. Biomol. Tech., 21: 163-166.

Soares, S., J. Amaral, M. Oliveira, and I. Mafra. 2013. A SYBR Green real-time PCR assay to detect and quantify pork meat in processed poultry meat products. Meat Sci., 95: 115120.

Ståhlberg, A., and M. Kubista 2018. Technical aspects and recommendations for singlecell qPCR. Mol. Aspects Med., 59: 28-35.

Stellwagen, N. C. 1998. DNA gel electrophoresis. Nucleic acid electrophoresis laboratory manual. D Tietz,. Springer Verlag, BerlinHeidelberg-New York.

Sudjana. 2005. Metoda Statistika Cetakan III. Tarsito, Bandung.

Zulaekah, S., dan Y. Kusumawati 2015 Halal dan haram makanan dalam islam. SUHUF, 17: 25-35. 